\title{
ANISOTROPIC SPACES IN ROMANIA: A CASE STUDY OF THE TIMIŞ-CERNA CORRIDOR
}

Remus Crețan, Sebastian Jucu, Maria Antoni

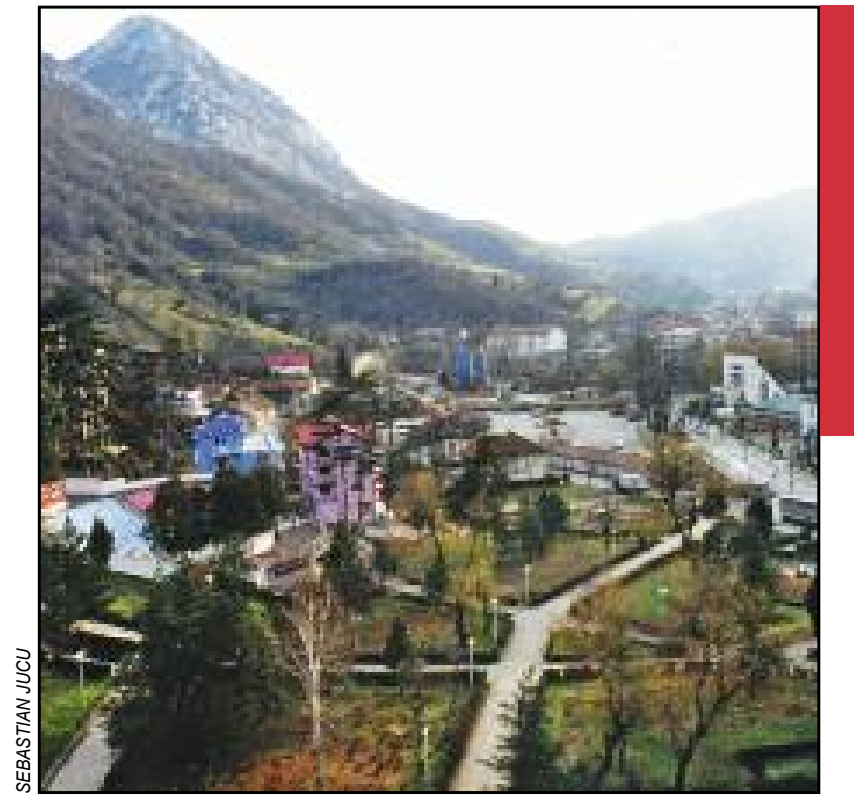

General view of Băile Herculane and the Cerna Valley. 


\section{Anisotropic spaces in Romania: a case study of the Timiş-Cerna Corridor}

DOI: http://dx.doi.org/10.3986/AGS.840

UDC: 913:314.15(498)

COBISS: 1.01

ABSTRACT: This paper presents a critical discussion of Romania's south-west, analyzing the proposal that the Timiş-Cerna Corridor should be systemically considered anisotropic. The aim of our paper is to test the possible anisotropic matrix system by using a methods approach based on interpreting human and material mobilities in the area. We use the theoretical framework of regional geography in a systemic context and specifically the concept of anisotropy defined as a territorial anomaly in homogenous and polarized regions, in order to reveal the social and physical relations in which anisotropy is embedded. Our results show that the Timiş-Cerna Corridor is an anisotropic area fitting the structural system of this specific type of space as the dynamics of flows inside the axis are asymmetrical, generating disparities, while transit flows are predominant.

KEY WORDS: geography, anisotropic spaces, human flows, material flows, the Timiş-Cerna corridor, Romania

The article was submitted for publication on May $31^{\text {st }}, 2014$.

\section{ADDRESSES:}

Remus Crețan Ph.D.

West university of Timişoara, Faculty of chemistry, biology and geography Bulevardul Vasile Pârvan, no 4, 300233 Timişoara, Romania E-mail: ioan.jucu@e-uvt.ro

\section{Sebastian Jucu Ph.D.}

West university of Timişoara, Faculty of chemistry, biology and geography Bulevardul Vasile Pârvan, no 4, 300233 Timişoara, Romania

E-mail: sebastian.jucu@e-uvt.ro

\section{Maria Antoni Ph.D.}

West university of Timişoara, Faculty of chemistry, biology and geography Bulevardul Vasile Pârvan, no 4, 300233 Timişoara, Romania

E-mail: antoni_maria26@yahoo.co.uk 


\section{Introduction}

Located in south-western Romania, the Timiş-Cerna Corridor is a geomorphological discontinuity (Ielenicz 1998) which separates two major Carpathian ranges (the Retezat-Godeanu Mountains of the central Carpathians in the east and the Banat Mountains in the west), connecting the Timiş Plain in the north and the Danube in the south. It links two economic development areas, the West and the South-West Regions, extending over three counties: Timiş, Caraş-Severin and Mehedinți. The Corridor is a complex area containing a network of multiple geographical features. It has an elongated form up to the valleys of the Timiş and Cerna rivers, notable for its serial succession of polarizing centers. It evolved from the concentration of habitats and economic activities alongside major transport routes.

Through its specific position in Romania's functional landscape, the Timiş-Cerna Corridor has been posited as 'a regional space with typical anisotropic features' (Boțan and Ilovan 2006). Thus this study follows a concept of region typology, the anisotropic region, and the way in which Timiş-Cerna Corridor fits the specific elements for this type of space. The question we have set is whether this corridor is anisotropic. The purpose of the study is to identify specific geographical elements which work together for the functionality of the axis and to test its anisotropy from a mobility perspective.

\section{Theoretical framework}

A wide-ranging scholarly literature has been written on the background definitions of a region (Blache 1908; Haggett 1990; Paasi 1991; Claval 1993) as well as its structure and functionality (Dauphiné 1997; Ianoş 2000).

The concept of anisotropic spaces was introduced into geographical sciences by Dauphiné $(1979,127$, an anisotropic region being " a territorial anomaly of the homogeneous and polarized regions". Dauphinés perception of anisotropic regions was developed from analysing the alongated represention of the Lorraine region, France, which is structured by the hydrographic axis of Moselle, in which roads, railways and urban networks are intermingled. The concept of anisotropy is used not only in seismology and physics (Helbig 1994), but also in geography. Important contributions to this concept were brought into Romanian literature by Cocean $(2010,107)$, who defined the concept as »elongated spatial entities (strip, axis, corridor), characterized by the existence of several successive polarizing centers united in a series. "Thus, one of the most important features of the anisotropic region is its structural and functional asymmetry.

According to Dauphiné (1979), the main element in an anisotropic space is the central privileged axis along which the completely regional entity is organized, other elements being of lesser importance. The presence of the development axis is crucial in anisotropic regions, with a significant role for the complex material, energy and information flows to and from the surrounding regions.

The structure of an anisotropic area is characterized by its configuration along a major axis marked by complex overlapping energy, material and information flows. The region has to be polarized not by a single center but by small polarizing centers partially influencing the region. The material, energy and information flows in such regions are always asymmetrical (functional asymmetry), resulting in uneven functionalities, hierarchies and functional disparities (Dauphiné 1979). Their origin is in the concentration of habitats and activities along the rivers and the main transport routes, and in the morphological corridors and elongated depressions (Cocean 2010).

Anisotropic spaces function as definite territorial systems with positive feed-back circuits. Consequently they form irreversible spatial structures (Dauphiné 1979). The energy, material and information flows are generated both inside and outside the region by the large polarizing centers situated along the axis. Such a space integrates the features of the homogenous and polarized areas, while the longitudinal orientation dominates (Cocean 2010). The polarizing areas of the centers in a regional system have a partial isotropy.

An anisotropic region may be temporary. It may evolve, intensifying its flows and crystallizing its specificity, or it may regress under the impact of certain centrifugal forces, collapsing to an inferior category of anisotropic area, or fragmenting while attaching to other territorial systems. Thus, local places and regions can be (re)created and reproduced as part of regional transformation of the society (Paasi 1991). Focusing on the intensity of the nucleation phenomenon inside a studied anisotropy (Dauphiné 1979), one can state that, according to its evolution, it could determine an endogenous nucleation type (Cocean 2010). This is due to the impact of univocal or bi-univocal transit processes in areas with reduced or strong lateral contribution. 
On the other hand, high transit (of passengers and materials) could be another characteristic of an anisotropic space. As Tim Cresswell (2014) states, geographers studying mobilities must think how things move and what are the meanings given to those movements. Intensification of flows of people, materials and information are included in a wide web of socio-economic scales and are widely supported by an intricate network of technologies and actors (Urry 2007). 'Mobile lives' (Elliott and Urry 2010) are key elements in understanding anisotropy, as specific forms of capital has recently generated 'new mobilities paradigm' (Urry 2007; Sheller and Urry 2006) which require a systemic analysis.

\section{Contextualizing the Timiş-Cerna anisotropy}

The various characteristics of the Romanian landscape, including its positioning in concentric levels, and the abrupt contact of the major landforms and valley corridors with at least one route for transport and the seashore, are favorable for the identification of territorial units with anisotropic features displaying a certain geographical specificity (Cocean 2010). As such, Boțan and Ilovan (2006) revealed several anisotropic regions in Romania, the Timiş-Cerna Corridor being considered one of those with anisotropic features (Figure 1). Within some of these regions the so-called 'double anisotropy phenomenon' is developed.

The geographical space of the studied area represents an important axis for material, energy and information flows as well as a specific space with an array of internal relations. Through its specificities, this space is unique (Ianoş 2000), its major role being the possession, at regional and national level, of upstream and downstream areal connections through different flow categories. The corridor's functionality is determined by the characteristics of the major structures, by its overlaps on a divided graben in three sectors, with two narrower sectors towards the extremities and a central one with a wider extension. The evolution of this space is influenced by natural laws with geographical relations altered by human action. This impact is obvious on the axis but also in various places on the mountain slopes.

The corridor comprises a development axis which spreads along the Timiş River continuing southwards to the Cerna river (Figure 2). Hence, there is a main axis comprising two individual contiguous axes, one an extension of the other, in a longitudinal north-south direction. One example is the Timiş Valley axis, with Caransebeş as a polarizing urban center, several rural centers (Buchin, Bucoşnița, Slatina Timiş, Armeniş, Teregova), plus the Cerna river axis, with a series of sequential polarizing rural centers (Luncavița, Domaşnea, Cornea, Bolvaşnița, Mehadia, Topleț). In the southern extremity is the town of Orşova. Along the main axis, there are two secondary axes with a perpendicular orientation, the Mehadica river axis, with the rural centers Mehadica, Lăpuşnicel and Iablanița, and the Sebeş river axis, with the rural center Turnu Ruieni.

The main direction of the natural processes is longitudinal, with vectors of running waters and river deposits. The transversal direction is created by the processes resulting in mountain slopes. This axis has a bi-univocal character presenting an ambivalent open loading and downloading aspect. Its extremities form a reception funnel concentrating the flows inside the axis (Cocean 2010). The main dynamic factor is due to "the transit, characterized by a movement of flows in both directions « (Ianoş 2000), appearing as a classical specific entity to tectonic corridors. An asymmetrical space is evident on both axis sides, with an inferior role in the structural matrix of the space. This asymmetry results from the morphology of the region, separating the Carpathian ranges.

Structurally, the Timiş-Cerna area is based on the hydrographic network and communication routes. The Corridor develops along two rivers (Timiş and Cerna) as well two major transport routes, an international railway and a European road. The Timiş river has the most important role in this area, connecting the geographical units of the northern extremity of the region and collecting waters from the entire area. It receives tributaries symmetrically from the Semenic and Țarcu Mountains. Cerna, the second river, contributes to the formation of the Corridor.

Transport routes of the area are important, especially the M1 Bucharest-Timişoara-Belgrade (M900) railway in a $79 \mathrm{~km}$ stretch between Orşova and Caransebeş. Routes also include two short forest railways in the Hideg Valley and the Long River Valley, connecting to the main line at Teregova and Armeniş. From the main network, a secondary railway separates, connecting the flows towards Reşița. The E70 European 


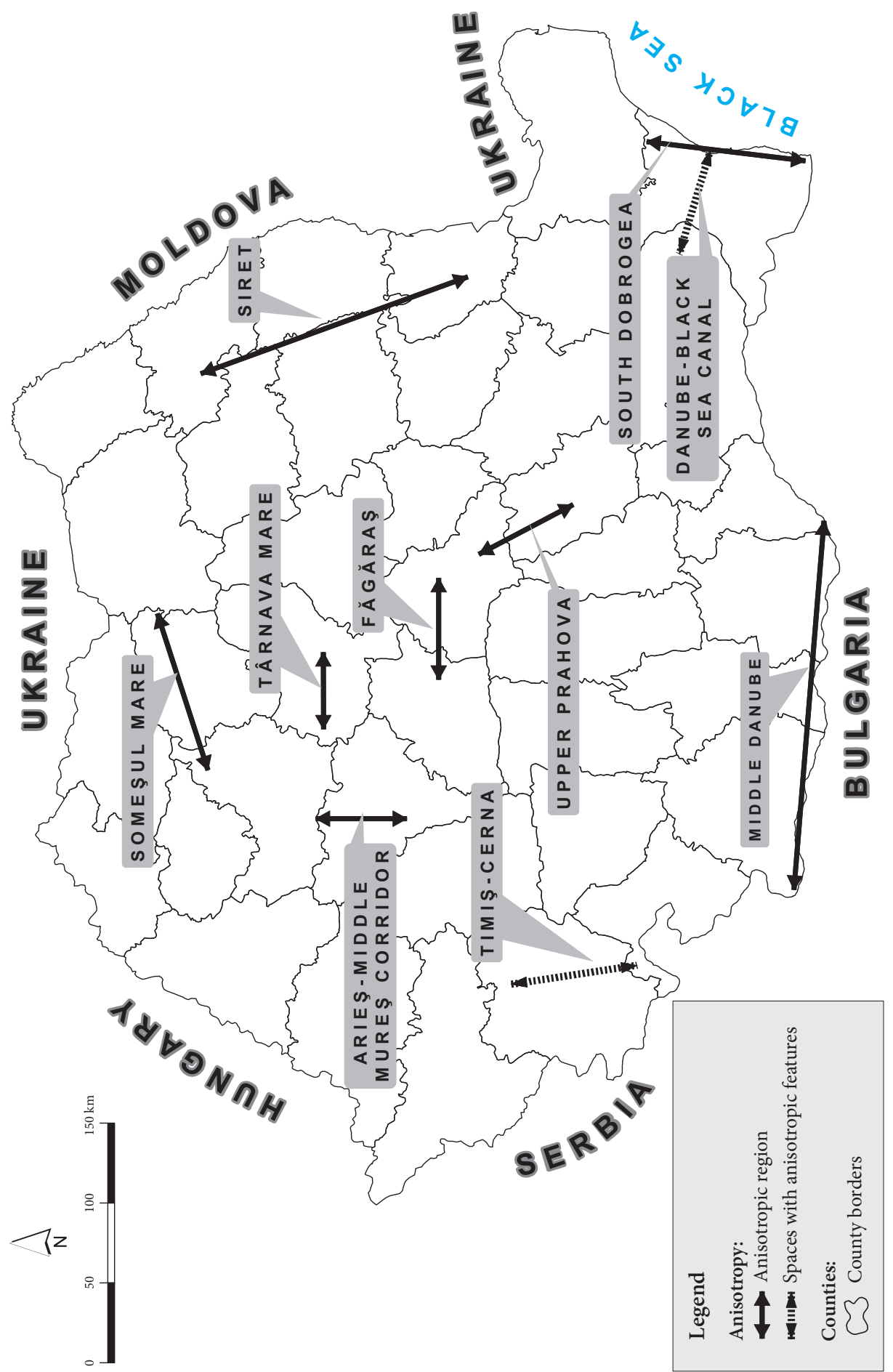




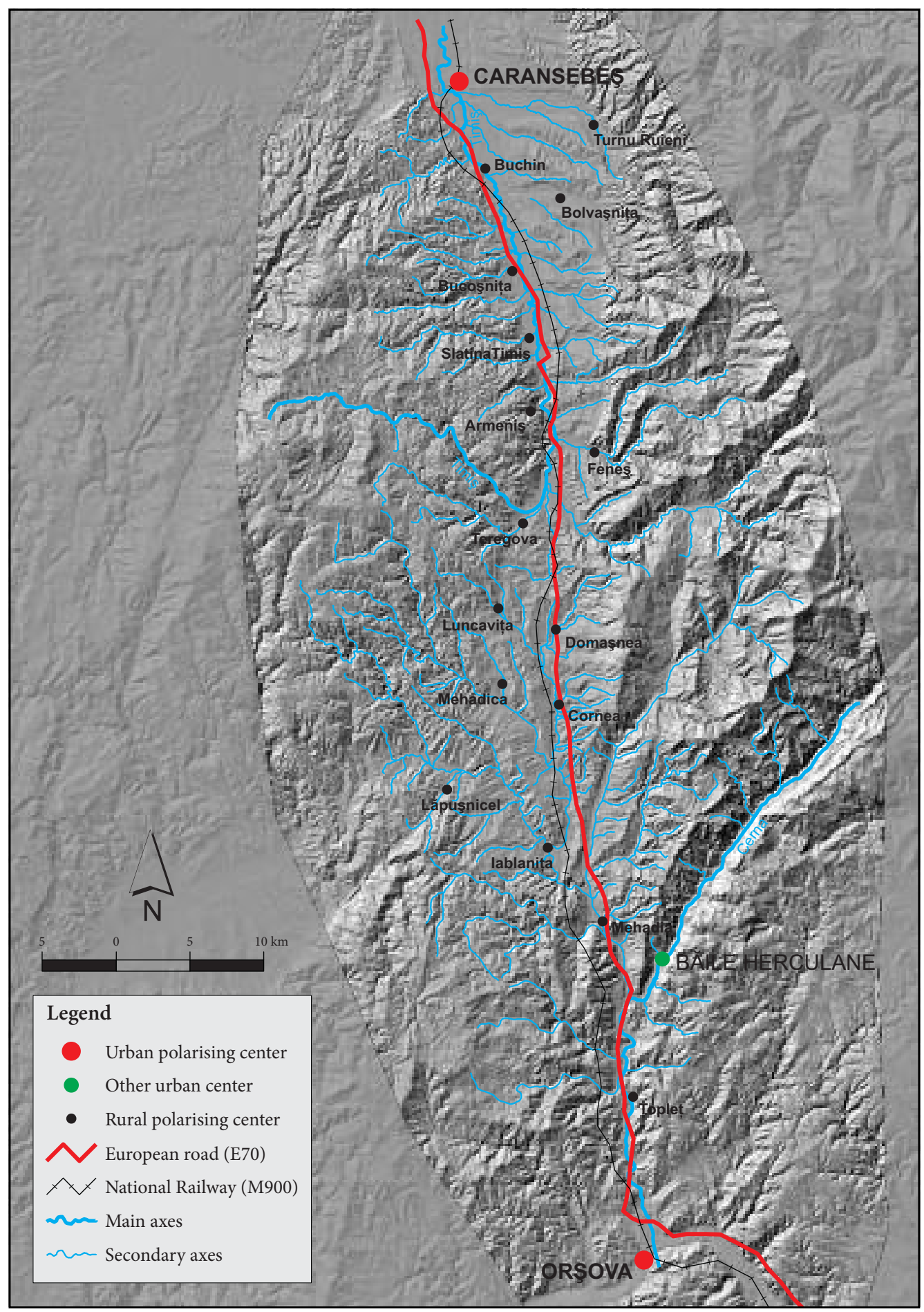

Figure 2: The anisotropic axis Timiş-Cerna. 
Road, between Orşova and Caransebeş, crosses the Corridor for $90 \mathrm{~km}$. It overlaps the old Roman road which linked Direna to other Roman provinces and which in the Middle Ages linked the craft and trade centers of Banat and Oltenia. The National Road DN6 crosses the same route with many links between the local urban and rural sites.

Human occupancy in the Timiş-Cerna axis dates from the Roman period, when this axis was well populated, as proven by the castrae from Dierna, Aquae (Băile Herculane) and Meedia (Mehadia), which were compulsory transit points to Sarmizegetusa Ulpia Traiana, as access routes also to Ad Pannonius (Cornea and Teregova) and Praetorium (Plugova). Many settlements appeared in the $16^{\text {th }}$ and the $17^{\text {th }}$ centuries, the present settlement network becoming distinct in the $20^{\text {th }}$ century. The present rural system comprises 15 communes and 52 villages attracted by two urban poles, Caransebeş in the north and Orşova in the south. A number of ethnicities have lived together for centuries in this area: Romanians, Germans, Serbians, Czechs, Hungarians, Gypsies, Jews and Ukrainians (Crețan 2006). Different identities have contributed to a common heritage and cultural diversity, as region-specific structures of expectations are influenced by how people contextualize the meanings in personal life histories (Paasi 1991).

\section{Methods and data sources}

The anisotropy of the Corridor was tested using the perspective of human and material flows, with a specific set of data and methods. For identifying human mobilities, we followed a three methods approach: the population dynamics for each town and commune, the tourist flows, and the railway transportation flows. In the first instance, data from the Population Census of Romania (2011) helped us understand the local and regional dynamics of population. Data from Asociația Națională a Agențiilor de Turism Caraş-Severin (2012) were very useful in showing the origin and destination of tourists in the studied area during 2011. For the third approach, the railways ticketing offices of SNTFC - Călători SA offered data on passenger flows (SNTFC 2012) and we followed the method of Estimated Passenger Flows (Myojo 2006). We considered a sample of flows counting using the OD (Origin and Destination) pairs in each partitioned period of a day, during April 4-10, 2012. We made the following steps: select a pair of OD from OD data gathered from ticket offices; search all paths from those traveling the OD selected; calculate the number of passengers on the paths searched during each period; store the number of passengers calculated; repeat the procedures for each unit of the day until all pairs have been finished; calculate the total number of domestic and transit passengers that pass each link daily; and identify the nodes in the network in order to see spatial discontinuities.

We were then interested to see the intensity of material flows, rather than their expression in weight or their environmental impact. SNTFM-CFR (2012) provided data on raw materials mobility. A classical material mobility account on the flows of solid materials was made. Following the Material Flows Analysis (MFA), largely used in fields including regional and transport studies (Brunner and Rechberger 2005), the group of materials was divided into three main subgroups: minerals (metal ores and non-metallic minerals like stones, clays, etc.), fossil energy carriers (coal, gas, oil), and biomass (forestry, agriculture and fishery). Then we selected inner material flows and transit material flows in order to see which one is dominant. General passenger and material flows were then represented in a choreme, as data handling and representation are relevant in regional analysis (Field 2010).

\section{Discussing the functionalities of the Timiş-Cerna anisotropy}

Following the theoretical line of nucleation phenomena in anisotropic areas (Dauphiné 1979; Cocean 2010), we have identified two categories of mobilities (flows) - human and material - with both longitudinal and transverse manifestation.

Human flows are very useful in revealing anisotropy, as mobilities 'upset established orders' (Cresswell 2014). We find that population dynamics, represented by the different internal and external centers, are endowed with various rankings and influences both upstream, downstream and laterally. There are passenger flows with an extreme ordering, with loss of material and energy because of migration to other areas of Romania or to other countries, a situation similar to the central Transylvania area (Conțiu 2010). This is the case in 
southern Timiş-Cerna, with the external town Drobeta-Turnu Severin and even the distant capital Bucharest attracting segments of the active population. The internal urban centers attract population from the rural settlements regardless of their distance. The demographic flows show the movement of people from their native village to the communes, and the displacement of later generations to urban centres. Moreover, the natural population is decreasing continually, simply due to a low birth rate (9.2/1000 persons).

The urban centers Orşova and Caransebeş polarize the region by their location and hierarchical position in the Romania urban system. The towns in rank I are allochthonous, while the inner towns of the Corridor are of rank II (Table 1).

Table 1: Towns with polarization function inside and outside the Timiş-Cerna area (Population census of Romania 2011).

\begin{tabular}{llcc}
\hline Number & Town & Rank in the anisotropic area & Number of inhabitants \\
\hline 1. & Lugoj (allochthone) & $\mid$ & 44,590 \\
2. & Drobeta-Turnu Severin (allochthone) & $\mid$ & 106,237 \\
3. & Caransebeş & $\|$ & 28,456 \\
4. & Orşova & $\|$ & 12,726 \\
5. & Băile Herculane & $\|$ & 5,966 \\
\hline
\end{tabular}

The communes (rank III) sequentially polarize the rural centers of the axis. The most important polaizing communes are Teregova, Domaşnea and Mehadia. In this line, as Kladnik and Ravbar (2003) demonstrated, the division of the countryside is very important in a regional development context.

Another factor in analyzing anisotropy relates to passenger flows. Following the railway estimated passenger flows method (Myojo 2006), we found that the OD pair totally belonging to the corridor (Caransebeş-Orşova/Orşova-Caransebeş) has a very high proportion of daily transit passengers (Table 2). This is due to including transit railway connections (Timişoara-Bucharest/Bucharest-Timişoara) in our study.

Table 2: Caracteristics of the OD railway pairs, including daily passenger values (SNTFC-CFR-Călători SA 2012).

\begin{tabular}{llcccc}
\hline Number & Origin-Destination Pairs & $\begin{array}{c}\text { Daily travelling } \\
\text { trains (No.) }\end{array}$ & $\begin{array}{c}\text { Average number } \\
\text { of daily passengers }\end{array}$ & $\begin{array}{c}\text { Average number } \\
\text { of daily transit passengers }\end{array}$ & $\%$ \\
\hline 1. & Caransebeş-Orşova; & 8 & 2433 & 1933 & 79.4 \\
& Orşova-Caransebeş & 8 & 2112 & 1906 & 78.3 \\
\hline 2. & Caransebeş-Reşiț; & 6 & 592 & - & - \\
& Reşița-Caransebeş & 6 & 466 & - & - \\
\hline 3. & Caransebeş-Timişoara; & 7 & 2311 & - & - \\
& Timişoara-Caransebeş & 7 & 2322 & 1655 & 86.7 \\
\hline 4. & Orşova-Bucharest; & 6 & 2476 & 1986 & 77.7 \\
\hline
\end{tabular}

Polarization is partial inside the corridor, as in Buchin and Topleț; thus, a pseudo-isotropic phenomenon is generated. Teregova, Domaşnea and Mehadia are core polarizing rural nodes. They have an urbanization trend - a reality reflected in the higher proportion of passengers attracted at rural level. Both traditionally attracted railway commuters from neighboring villages. The rank III settlements assume the role of pseudo-isotropy confluences, mediating the process of connection between the access railways. Moreover, the atrophic feature includes polarizing centers in competition known as spatial aggregation nuclei (Cocean 2010). Correlating our results with the statistics offered by the Population Census of Romania (2011), we discover that some of the former industrial communes in the communist period (such as Topleț, Armeniş and Buchin) now have a dominant female labor force, with men preferring to commute to work in Orşova, Băile Herculane and Caransebeş. After calculating the total number of domestic passengers who use each railway link daily, we conclude that the three autochtonous towns held almost $80 \%$ of the internal valley corridor's railway destination flows. 


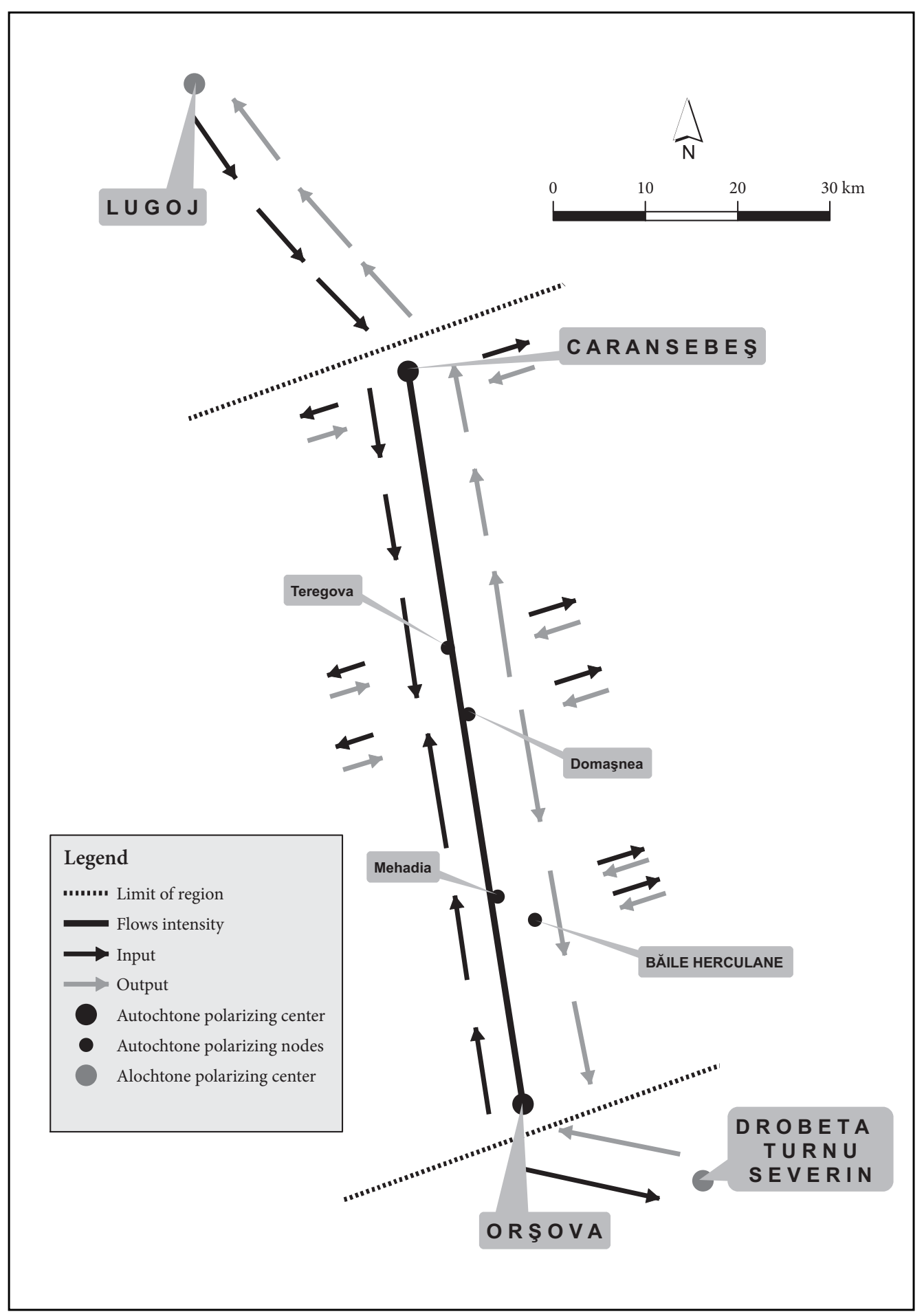

Figure 3: Flow orientation and intensity in the Timiş-Cerna Corridor. 
Touristic flows are figured by Orşova, a port on the Danube connecting Eastern Europe and the Black Sea, and mainly by the resort of Băile Herculane, an important tourist town, with a random positioning from the development axis on its eastern side of the Cerna river. The resort attracts $84 \%$ of the tourist flows in the Timiş-Cerna Corridor (ANAT 2012). Only a quarter of the tourists are autochtonous and few (16\%) are registered as foreign tourist flows.

Material flows consist of minerals (21\%), fossil energy carriers (35\%), and biomass (44\%). Brown coal is extracted in the south of the Domaşnea-Mehadia Depression and transported along and outside the corridor. The exploitation of construction rocks, granite and, feldspars is notable on both sides of the axis (Linc 2001, 55). Agricultural products (as a main biomass subcategory) are also important in these flows (27\%). Industrial products are mainly represented by wood processing (cellulose and paper) and the food industries at Caransebeș. They are distributed to several big cities of the Banat and southern Romania. In general, most of the industrial products are destined for other areas of Romania (Figure 3 ).

The final findings of the study refer to accounting the proportion of transit flows. It is notable that about $80 \%$ of the total railway passenger flows are created by transit flows. About $25 \%$ of these transit flows result from goods transportation inside the area and $75 \%$ feature transit through the corridor. Due to this allochthonous polarization, a large part of material and energy entries in this system do not remain within the Timiş-Cerna Corridor. Consequently, an important characteristic of the Timiş-Cerna space is transition.

Analyzing the choreme of matrix structure in the Corridor, both its extremities reveal the presence of two urban centers, providing important interfluent and continuous demographic and material flows in the Corridor. Lugoj municipality is in the northern part and Drobeta-Turnu Severin in the southern sector. The polarization provided by the urban allochthonous centers (Figure 4) is a common characteristic for the majority of anisotropic regions in Romania.

\section{Conclusion}

This contribution analyzed the functional features of the Timiş-Cerna area considering anisotropy as a key concept in spatial polarization. It is an anisotropic area fitting the structural matrix of this specific type of space. This argument is based on two main findings: from a spatial perspective it develops along the main privileged axis up to Timiş-Cerna; the axis supports complex and overlapped human and material mobilities (flows).

As a developing axis it is influenced by several centers, each polarizing the area differently according to its ranking in the Romanian urban system hierarchy. The inner flow dynamics, on which functional inequalities, hierarchies, functional disparities and uneven fluxes are based, are asymmetrical. This shows how physical mobility has fundamentally transformed a regional society, and has spanned new modes of social and material interaction (Urry 2007). Mobile lives (Elliott and Urry 2010) and 'new mobilites paradigm' (Sheller and Urry 2006) based on different flow dynamics are core elements of spatial interpretation for anisotropic areas.

The entire regional functions determine irreversible spatial structures, confirming Dauphinés theory (1979), the dynamics of the mobilities in the axis being conducted from both within and outside. The Timiş-Cerna Corridor clearly combines the characteristics of homogenous areas with those of polarized areas. Nodes appear within, due to the polarization of different ranking centers. Where polarization is partial, a local scale pseudo-isotropic phenomenon appears.

\section{Acknowledgements}

We have to thank the anonymous reviewers and the editors of Acta Geographica Slovenica for their suggestions on improving the paper. Special thanks are due also to Fabian Timofte (West University of Timisoara) and Paul Woodman (independent researcher, UK) for their comments on maps and previous versions of the manuscript. This work was supported by the strategic grant POSDRU/159/1.5/S/133391 »Doctoral and Post-doctoral programs of excellence for highly qualified human resources training for research in the field of Life, Environment and Earth Science " co-financed by the European social fund within the Sectorial operational program human resources development 2007-2013 


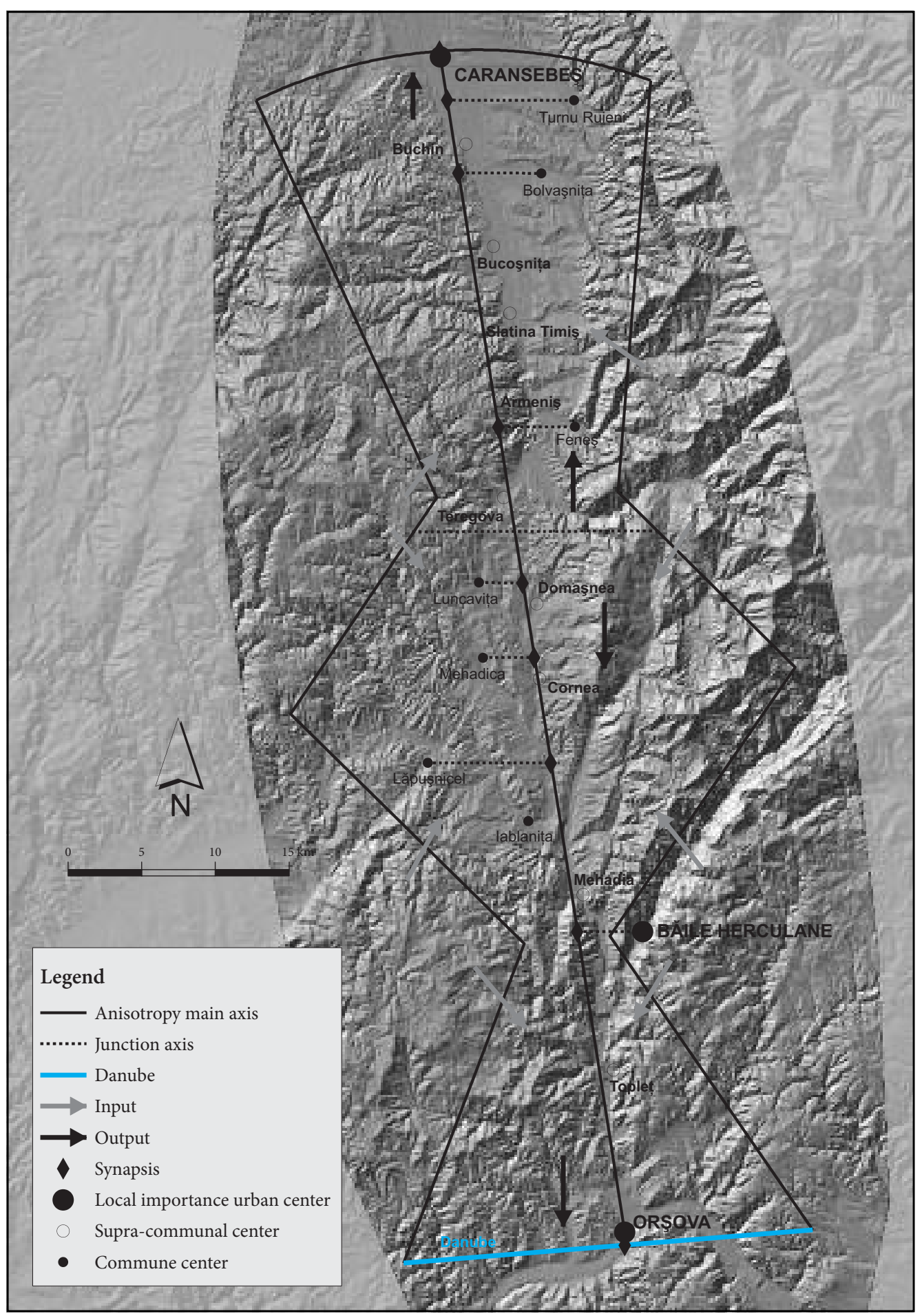

Figure 4: Chorema of matrix structure in the Timiş-Cerna Corridor. 


\section{References}

Asociația Națională a Agențiilor de Turism - ANAT 2012: Fluxurile de turişti români şi străini. Bucharest. Blache, P. V. de la 1908: Régions naturelles et noms de pays. Paris.

Boțan, C. N., Ilovan, O. R. 2006: Sălăuța valley anisotropic space, structure and functionality. Lucrările seminarului geografic Dimitrie Cantemir 26.

Brunner, H., Rechberger H. 2005: Practical handbook of material flow analysis. London

Claval, P. 1993: Initiation à la geographie régionale. Paris.

Cocean, P. 2010: Geografie regională. Presa universitară Clujeană. Cluj-Napoca.

Cocean, P., Boțan, C. N. 2007: Regiunea anizotropă a Someşului Mare, structură şi funcționalitate. Studia UBB Geographia 52-2.

Conțiu, A. 2010: Axele de gravitație regionala ale Târnavelor. Cluj-Napoca.

Cresswell, T. 2014: Mobilities III: moving on. Progress in Human Geography 38-5.DOI: http://dx.doi.org/ $10.1177 / 0309132514530316$

Crețan, R. 2006: Etnie, confesiune şi opțiune electorală în Banat. Structuri teritoriale, tradiție, actualitate. Timişoara.

Dauphiné, A. 1979: Espace, région et système. Paris.

Elliott, A., Urry, J. 2010: Mobile lives. London.

Field, R. 2010: Data handling and representation. Key methods in geography. London.

Haggett, P. 1990: The geographer's art. Cambridge.

Helbig, K. 1994: Foundations of anisotropy for exploration seismics. Handbook of geophysical exploration: seismic exploration 22. Utrecht.

Ianoş, I. 2000: Sisteme teritoriale. O abordare geografică. Bucharest.

Ielenicz, M. 1998: Le concept de discontinuité en géographie. Revue Roumaine de Géographie 42.

Kladnik, D., Ravbar, M. 2003: The importance of the division of the countryside in stimulating regional development. Acta Geographica Slovenica 43-1. DOI: http://dx.doi.org/10.3986/AGS43101

Linc, R. 2001: Culoarul Timiş-Cerna. Studiu de geografie fizică. PhD Thesis. Babes-Bolyai University, Faculty of Geography. Cluj-Napoca.

Myojo, S. 2006: A method to estimate passenger flow using stored ticket gate data. Quaterly Report of RTRI (Railway technical research institute) 47-4.

Paasi, A. 1991: Deconstructing regions: notes on the scale of spatial life. Environment and planning A 23-2. DOI: http://dx.doi.org/10.1068/a230239

Population census of Romania 2011: Demographic data, Caraş-Severin county. Bucharest.

Sheller, M., Urry, J. 2006: The new mobilities paradigm, Environment and planning A 38 - 2. DOI: http://dx.doi.org/10.1068/a37268.

SNTFC-CFR-Călători SA 2012: Registrul de ticketing călători. Caransebeş.

SNTFM-CFR - Societatea națională de transport feroviar marfă 2012: Destinația mărfurilor de transport, pe tipuri de marfă. Caransebeş.

Urry, J. 2007: Mobilities. Cambridge. 